\title{
Hvordan bliver studerende aktive i fjernundervisning?
}

\section{Brug af en trinvis, struktureret model til fremme af interaktion og læring}

\author{
Anita Monty \\ IT vejleder \\ IT Learning Center \\ Kgl. Veterinær- og Landbohøjskole \\ www.kvl.dk/itlc
}

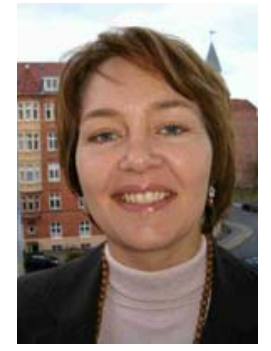

\section{Carsten Smith Olsen}

Lektor, PhD

Center for Skov, Landskab og Planlægning

Kgl. Veterinær- og Landbohøjskole

www.sl.kvl.dk

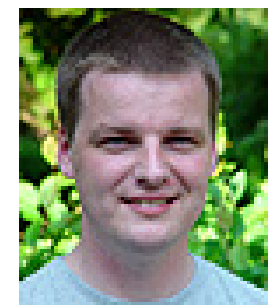

Anita Monty er cand.mag. i pæedagogik fra Københavns Universitet med speciale i e-lcering. Har tidligere arbejdet på Danmarks Pcedagogiske Bibliotek, DPU. Siden 1. april 2005 ansat som IT-vejleder i IT Learning Center, KVL. Arbejder med at vejlede KVLs undervisere i teknisk og pcedagogisk brug af e-lcring.

Carsten Smith Olsen arbejder med forskning og uddannelse inden for tropisk skovbrug. Har de sidste fire år veret involveret i udvikling af distance undervisning til brug på MSc programmer, herunder iscr opbygning af kurser og praktisk implementering. Interesseområder er institutionel organisering af e-learning og pcedagogiske aspekter i forbindelse med distanceundervisning.

\section{Indledning}

Den Kongelige Veterinær- og Landbohøjskole (KVL) har siden 2002 arbejdet strategisk og målrettet med at udvikle og udbyde undervisning som ren fjernundervisning på nettet. Erfaringerne fra de første år viste, at den største udfordring var at skabe engageret dialog på et højt fagligt niveau (Olsen et al. 2004). Denne udfordring er søgt løst ved at bruge Gilly Salmons five-stage model (Salmon 2004), som er en trinvis, struktureret model der lægger vægt på at fremme interaktion mellem deltagere i læreprocessen. Underviserens primære rolle er at facilitere de studerendes tilegnelse af ny viden, i særdeleshed ved at fremme videnskabelse i mindre grupper. Denne artikel beskriver kort modellen, og de erfaringer, der er opnået med at bringe den i anvendelse på KVL. Desuden kommenteres på underviserens nye rolle i forhold til de studerende, og der afsluttes med betragtninger om, hvorledes modellen kan videreudvikles.

\section{E-læring er en ny kontekst for læring}

Brugen af informations- og kommunikationsteknologi i det sen-moderne samfund udfordrer vores etablerede forestillinger om undervisning og læring (Slevin 2006). Ser vi på læringsmiljøet, så var det tidligere associeret til auditorierne, undervisningslokalerne og tekst- 
bøgerne, men i dag giver internet og trådløst netværk nye muligheder for adgang til læringsmaterialer. Læring og kompetenceudvikling kan nu foregå på et hvilket som helst tidspunkt og sted. Det afspejler sig i denne definition af læringsmiljø fra Indiana University: ” $A$ physical, intellectual, psychological environment which facilitates learning through connectivity and community" (Beard \& Wilson 2005). Bemærk begreberne "connectivity" og "community". De understreger, at vi må anskue e-læring som en ny kontekst for læring, og ikke blot som et værktøj (Bates \& Poole 2003, Salmon 2004).

Den nye kontekst kræver, at vi tænker over, hvordan vi kan gennemføre undervisning online. Det er der flere grunde til. For det første viser vores erfaringer fra KVL, at det ikke er muligt at opnå succesfuld undervisning online ved at benytte de former for undervisning, som vi normalt anvender i universitetsundervisning med fysisk tilstedeværelse, dvs. dialogbaseret forelæsning og holdundervisning, hvor underviseren er den primære leverandør af facts og viden. Undervisning må i højere grad baseres på mulighed for aktiv interaktion og dialog mellem studerende og undervisere, hvor læring er noget man som studerende selv er med til at skabe. Via e-læringsteknologi er det muligt at lære ved at skabe kontakter og opsøge netværk ("connectivity”) samt indgå kvalificeret i disse ("community"). Men det kræver, at online undervisning er tilrettelagt sådan, at de studerende kan udnytte mulighederne. For det andet er der ændrede samfundsforhold, som i højere grad kræver, at studerende udvikler nye kompetencer til at begå sig. Slevin (2006) peger på, at succesfuld ageren i dag i stigende grad er baseret på beslutninger, som er taget på baggrund af viden og kompetence, som kan vise sig pludselig at være forældet. Det sen-moderne videnssamfund kan karakteriseres som et samfund med øget risiko (men på den anden side også øgede muligheder). At leve i en sådan verden kræver vores aktive engagement. De studerende har derfor brug for at udvikle kompetencer til at handle aktivt og engageret gennem dialog med individer, grupper og organisationer. Slevin peger på, at Salmons model giver de studerende mulighed for at udvikle disse kompetencer, og at den derfor er en tidssvarende model for online universitetsundervisning. Det erklærer vi os enige i, og vi vil forsøge at anskueliggøre dette ved at beskrive de erfaringer, vi har gjort os med brug af modellen på KVL. Men først en kort introduktion til modellen. For yderligere introduktion til modellen anbefales at læse Salmon (2002, 2004); yderligere kritiske kommentarer findes i Slevin (2006).

\section{Præsentation af five-stage modellen}

Gilly Salmon (2004) peger på, at distancestuderende har flere udfordringer end on-campus studerende, fordi de på samme tid skal lære at bruge et e-læringssoftware (Learning Management System), koncentrere sig om at tilegne sig det faglige indhold af et kursus, og samtidig overkomme den udfordring det er udelukkende at kommunikere skriftligt. Derfor er der, ifølge Gilly Salmon, brug for en undervisningsmodel, der tager højde for distancestuderendes særlige situation og for, at der er forskel på mundtlige og skriftlige kommunikationsformer. Hun bemærker også, at distancestuderende kan få skriveblokering ved tanken om, at deres indlæg i en faglig diskussion er permanente og kan læses af alle igen og igen. Det er således afgørende for god distanceundervisning, at der opbygges en særlig tryg og støttende atmosfære i det virtuelle e-læringsrum, så det ikke opleves som problematisk at deltage i de faglige dialoger. Salmons model er en trinvis, struktureret model, den såkaldte five-stage model (Figur 1), som bygger på ideen om stillads for læring. Salmon baserer sig på de sociale læringsteorier, og er således opmærksom på, at læring er socialt baseret, og at det lærende menneske har brug for en passende form for støtte fra omgivelserne, hvis dets læring skal optimeres. Modellen har nogle grundelementer, som har til formål at gøre de studerende aktive. Elementerne er:

1. Underviseren er e-moderator, dvs. har ansvaret for at igangsætte og være moderator af diskussioner i e-læringsforløbet. Det sker i praksis ved, at underviseren på forhånd 
har lavet e-tivities (online læringsaktiviteter), som de studerende skal udføre undervejs i kurset. Desuden skal e-moderatoren være den, der samler op i diskussionerne ved løbende at lave resuméer, hvor han eller hun fremhæver, hvad der har været diskuteret undervejs og kommer med faglige synspunkter og nye vinkler (f.eks. ved at slutte af med nye faglige spørgsmål til diskussion blandt de studerende). Med sin faglige ekspertise og overblik faciliterer underviseren dermed de studerendes læring.

2. E-tivities forløber over fem trin i modellen, hvor hvert trin indeholder et læringsmål for de studerende samt en beskrivelse af de tilhørende moderator opgaver på dette trin. Som eksempel kan nævnes, at på trin 1 i modellen er formålet, at de studerende logger på e-læringssystemet og får adgang til kurset. Moderatorens opgave på trin 1 er at sørge for at byde de studerende velkommen og være opmuntrende. E-tivities på trin 1 vil derfor være et velkomst indlæg, som de studerende skal svare på. Alle e-tivities har en deadline for udførelse. De efterfølgende trin rummer e-tivities, der er forskellige i deres læringsmål, men som alle er med til at lede de studerende frem til at kunne arbejde kollaborativt og deltage aktivt i en faglig dialog.

Modellen viser de enkelte trin med moderatorens opgaver (se i øverste del til højre af hvert trin i Figur 1) og læringsmål for de studerende (se i nederste venstre del af hvert trin i Figur 1). Aktivitetsindikatoren til højre for trinene viser, hvilken forventning der er til intensitet i interaktionen på de enkelte trin. På et kursus, der varer 10 uger, kan underviseren f.eks. fordele e-tivities inden for de fem stadier således: stadie 1-3 i to uger, stadie 4-5 i otte uger. Denne case er et kursus af 9 ugers varighed; dog anbefaler Salmon, at modellen implementeres på kurser, der varer mindst 10 uger, da det ellers vil betyde, at der ikke vil være tid nok til at arbejde sig igennem samtlige stadier (Salmon 2004).

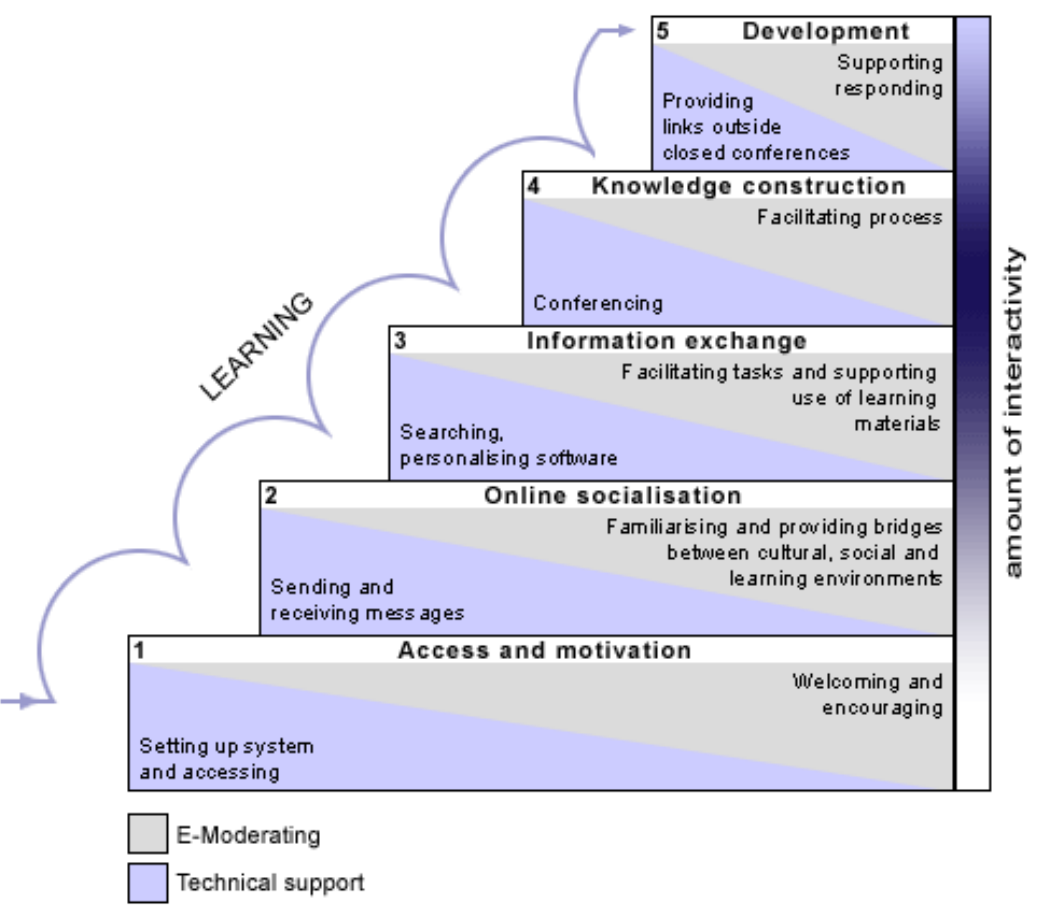

Figur 1. Gilly Salmons five-stage model (Salmon 2004)

Nedenstående er en kort beskrivelse af de enkelte trin i modellen:

Trin 1 - Access and motivation. Her er moderatorens opgave at motivere de studerende, fordi de skal tackle de tekniske udfordringer med at logge på e-læringssystemet, netadgang, osv. På trin 1 skal der være en varm velkomst fra e-moderatoren, som de 
studerende skal svare på. Udfordringen for de studerende på dette trin er at få logget sig på, finde vej til deres e-læringskursus og som nævnt svare på et indlæg. Der skal ikke være yderligere udfordringer for de studerende, for ellers kan motivationen tabes. Det er vigtigt at etablere en god mulighed for de studerende til at opnå support via telefon og/eller e-mail. På trin 1 er behovet for individuel hjælp større end på andre stadier. Trin 1 er overstået, når de studerende har postet deres første indlæg.

Trin 2 - Online socialization. De studerende er begyndt at vænne sig til at være i det nye virtuelle læringsmiljø. Nu skal e-moderatoren skabe muligheder for online socialisering. Via diskussion og forhandling bliver der skabt et særligt lille kulturelt rum for denne gruppe af mennesker. Mange deltagere bliver begejstret over muligheden for at dele tanker, erfaringer og opgaver med de andre, men synes også, at det kan være svært at få startet. Trin 2 handler om at få skabt tillid, som ikke bygger på og er afhængig af fysisk tilstedeværelse. Men fravær af fysisk tilstedeværelse skal anskues som et element til succes frem for en barriere. Fravær af fysisk tilstedeværelse giver blot andre fordele end at være fysisk sammen til undervisning. Mange moderatorer mener f.eks., at de kommer til at lære den enkelte studerende bedre at kende i e-læring.

Trin 3 - Information exchange. Nu træder det teknologiske i baggrunden, og de studerende begynder at opfatte e-læringssystemet som et aktivt, levende humant netværk. De bliver begejstret over den øjeblikkelige adgang til information fra andre studerende. Men det kan også være overvældende. E-moderatoren har til opgave at sørge for, at alle har en rolle at spille, og at alle deltager aktivt. Det gøres bedst ved at designe e-tivities, der opfordrer til aktivitet og til at opmuntre de studerende undervejs. E-moderatoren skal værdsætte og anerkende bidrag til diskussion og videndeling, men også verificere de studerendes bidrag, hvis der er brug for det. For den studerende er målet på trin 3 at lære at søge rundt i den mængde af information, der er tilgængelig, frem for at blive overvældet.

Trin 4 - Knowledge construction. Gilly Salmon mener, at det er vigtigt at få de studerende over trin 3 så hurtigt som muligt. For på trin 4 og 5 vil de studerende være i stand til at arbejde kollaborativt og skabe viden sammen. Men stadierne forinden kan ikke springes over, f.eks. er online socialisering (trin 2) en betydningsfuld forudsætning for senere at kunne arbejde kollaborativt. Som de faglige diskussioner tager fart her, så tager de fleste studerende del i en meget aktiv læreproces, især ved selv at formulere mere brede perspektiver samt ved at være åben over for perspektiver fra de andre studerende. De studerende lærer lige så meget af hinanden, som fra deres læringsmaterialer eller fra intervention fra en underviser. De udvikler kompetencer til at begå sig i videnssamfundet, især i den kreative kognitive proces, som det er at fremkomme med ideer, få dem kritiseret eller anerkendt/udvidet og ikke mindst chancen til at omforme og genskabe ideerne i lyset af diskussionerne med de ligestillede medstuderende. E-moderatorens rolle er løbende at "væve" indlæggene i diskussionerne sammen til et resumé. På trin 4 anbefaler Salmon, at e-moderatoren trækker sig en lille smule tilbage ved f.eks. at overlade moderator rollen til en studerende fra gruppen.

Trin 5 - Development. De studerende vil begynde at bygge videre på de tanker og ideer, som de har tilegnet sig gennem de fire trin forud, og bruge dem i forhold til sig selv. De bliver kritiske og selv-kritiske. Både studerende og e-moderatoren vil kreativt bruge deres deltagelse online. E-tivities på dette trin skal fremme refleksion og maksimere værdien af e-læring for den enkelte deltager og for gruppens erfaringer og læreproces. Det er en god idé at få de studerende til at vende tilbage og reflektere over de tidligere indlæg. 
Vi håber, at vi, med ovenstående beskrivelse af modellens stadier, klart viser, at modellen har en studentercentreret undervisningstilgang. Gilly Salmons læringsteoretiske grundlag er de sociale læringsteorier, og hun anser det netop for væsentligt, at de studerende konstruerer deres viden sammen (Salmon 2002, 2004). Derfor bliver underviseren en facilitator for de studerendes konstruktion af viden. Modellen er trinvis og struktureret, da dette tjener til at fremme den studerendes medvirken og dermed læring. Modellens form kan yderligere argumenteres at være en fordel for underviseren, da denne kan indsamle erfaringer på hver stadie og således mere effektivt lokalisere, hvilke e-tivities der virker eller netop ikke virker på de enkelte trin, så det bliver muligt at lave forbedringer på de stadier, hvor det er nødvendigt. Det giver i sidste ende en bedre læreproces for de studerende.

\section{Brug af modellen på et dansk universitet}

I dette afsnit beskrives kort casen (de to kurser hvori modellen er anvendt) samt de erfaringer, vi har opnået ved at omsætte modellen til praksis.

\section{Casen}

Vi brugte modellen på to kurser på den engelsksprogede to-årige MSc uddannelse i Agricultural Development (http://www.kvl.dk/uddannelse/kandidatuddannelse/ad.aspx) i efteråret 2005. Begge kurser er på 7,5 ECTS og omhandler aspekter af tropisk skovbrug (se om kurserne på http://kurser.kvl.dk/2005/2006/presentation.aspx?coursecode=290004 og http://kurser.kvl.dk/2005/2006/presentation.aspx?coursecode=310017). Al undervisning på ét kursus, inkl. eksamen, finder sted inden for en ni ugers periode; dette svarer til en arbejdsbelastning per studerende på ca. 20 timer per uge. De to kurser lå i forlængelse af hinanden. Der var 15-20 deltagere per kursus. Deltagerne er en blanding af danske og udenlandske studerende. De fleste havde før første kursus ingen erfaring med brug af informations- og kommunikationsteknologi (IKT) i undervisning. Kursusmateriale er hard copy kompendier, online øvelser og supplerende online materiale, f.eks. cases.

Hvert af kurserne startede med en to timers face-to-face session. Denne er frivillig (nogle deltagere opholder sig i udlandet) og fokuserer alene på at introducere det faglige indhold i kurset. Deltagerne får ingen introduktion til den anvendte software (ABC Academy); dog er en skriftlig vejledning til rådighed på både dansk og engelsk (Monty 2005). Hvert kursus er bygget op, således at den studerende gradvist, men hurtigt, bliver bekendt med softwaren. Deltageren skal alene have adgang til internet (min 56K) og en browser; der skal ikke installeres software.

Hvert kursus er opbygget af et antal moduler; typisk skal et modul fuldføres per uge. Hvert modul har samme struktur og består af elementerne Introduktion; Overblik; Læs; og Øvelser. En nærmere beskrivelse findes i Olsen et al. (2004). Øvelser består af multiple-choice opgaver og e-tivities. Førstnævnte giver den studerende mulighed for at checke, at hun har tilegnet sig grundlæggende terminologi og sammenhænge; i tilfælde af forkerte svar modtages straks feedback tekst, der redegør for, hvorfor svar er forkert. Sidstnævnte er opgaver, den studerende skal løse i samarbejde med andre studerende. Hver e-tivity er typisk bygget op omkring en Titel; Formål; Opgave; og Deadline. Et eksempel er givet i Figur 2. E-tivities er glimrende beskrevet i Salmon (2002). 


\section{E-tivity 1.4: Working with the first case}

Purpose: to gain experience with working together in the small groups on a case

Task: Read the newspaper article "They speak for the trees". You will find this case text under exercises in the "Paradigms in tropical forestry" module. You can also click here. Think about: (i) what is the main conflict described in the article? Can you describe the conflict in your own words? (ii) how can the conflict be explained using the forestry paradigms introduced in the compendium? Each group member should contribute to answering these two questions by posting messages and responding to comments. Your e-moderator will summarise the discussion.

Deadline: Friday 9 September 14.00 CET.

\section{Figur 2. Eksempel på opbygning af e-tivity}

\section{Fra model til praksis}

\section{Planlægning}

Grundlæggende ønskede vi at støtte de studerende gennem processen (i) læsning og refleksion over udvalgte emner (kompendium), (ii) checke forståelse af grundlæggende elementer indenfor hvert emne (multiple-choice og chats), og (iii) arbejde med og kritisk diskussion af hvert emne (e-tivities). Dette papir fokuserer i det følgende på erfaringerne fra (iii), dvs. vores arbejde med at strukturere e-tivities, skabe interaktion mellem studerende, fremme de studerendes muligheder for kritisk refleksion og fælles videnopbygning, og koble evaluering af den enkelte studerende tæt til det gennemførte arbejde. Følgende nøglepunkter blev overvejet i forbindelse med organiseringen af kurserne:

- Konsekvent struktur. Med udgangspunkt i vores hidtidige erfaringer (Olsen et al. 2004) og Salmons arbejde (2002) valgte vi at gøre vores e-tivities veldefinerede og afgrænsede. De er således alle bygget op på samme måde, jvf. ovenfor, og kan gennemføres indenfor en uge.

- Størst mulig flexibilitet. Vi ønskede at give de studerende størst mulig flexibilitet med hensyn til, hvor og hvornår de arbejdede med e-tivities. Næsten alle vores e-tivities er derfor opbygget som asynkrone netbaserede plenumdiskussioner. Dog er der også mange deadlines, typisk mindst én per uge, for at sikre afslutning af det enkelte modul.

- Stringent implementering. I hver e-tivity er der eksplicitte mål for og krav til deltagelse. Desuden er roller klart fordelt; f.eks. er enkelte studerende direkte udpeget før én etivity, hvis de har ansvar for at flette eller opsummere en diskussion. Underviseren viser sin virtuelle tilstedeværelse; dette er særligt vigtigt i modellens tre første stadier.

- Konsekvent individuel evaluering. Det blev tilstræbt at koble arbejdsformen (multiplechoice og e-tivities) så tæt som muligt til evalueringen af den enkelte deltager. I praksis betød det, at øvelserne, herunder e-tivities, talte $50 \%$ af den endelige karakter (de sidste $50 \%$ kom fra en afsluttede skriftlig eksamen). Hver e-tivity talte således 
med en given vægt (f.eks. 1\%) og endelig karakter blev givet udfra en skala fra 0$100 \%$ (f.eks. karakteren 10 for at slutte i intervallet 75-84\%).

- Deltager input til forbedring af kurser. For at sikre mest muligt input fra de studerende til den videre udvikling af kurserne indbyggede vi e-tivities, der fokuserede på refleksion over kursus indhold og form.

Salmon fremhæver betydningen af at (i) være godt forberedt til et forløb med e-tivities, og (ii) have en klar struktur for opbygning af kursussiderne i e-læringssystemet. Alle e-tivities er derfor planlagt inden kursusstart for at sikre, at der er tid for underviseren til at være moderator. Det var vores ønske fra start at gøre det trygt og overskueligt for de studerende at deltage i en skriftlig dialog. De studerende blev derfor delt op i mindre grupper af 4-8 personer, hvor de udelukkende kunne deltage i deres egen gruppe og ikke fik mulighed for at læse/skrive med i de øvrige gruppers arbejde. Hvad angår opdelingen i grupperne overvejede vi, om opdelingen skulle ske på forhånd, eller om der skulle være frivilligt gruppevalg. Men af hensyn til det korte tidsforløb (9 ugers kurser) var vi nervøse for, at der ville gå for meget tid med at opnå enighed om gruppeinddelingen blandt de studerende. Det er derfor ikke til at vide, om motivationen hos de studerende ville have været endnu højere, såfremt de selv havde dannet grupper. Desuden overvejede vi, hvorvidt vi kunne bevare trygheden ved små grupper samtidig med, at hver enkelt studerende fik mulighed for at kommunikere med de øvrige deltagere på holdet. For at skabe både et gruppetilhørsforhold og et holdtilhørsforhold, blev der udover grupperum oprettet diskussionsforum for hele holdet senere i forløbet.

Som nævnt ovenfor er det også i e-læring vigtigt at skabe en god struktur i et kursus. Det skal være klart og tydeligt for de studerende, hvor man læser information om e-tivities, hvor de skal udføres, hvor opgaver skal afleveres, multiple choice udføres, osv. Det er moderatorens rolle at tage vare på struktureringen af læringsrummet, i hvert fald i starten, og ellers at uddelegere opgaven til en studerende (Salmon, 2002). Vi skabte en særlig side i hvert modul med titlen "e-tivities", så de studerende let kunne få overblik over hvilke e-titivies, der skulle udføres i den pågældende uge, hvilke de havde udført i tidligere moduler, osv. Det tager tid at gennemtænke struktur og organisere e-læringsrummet. Til gengæld er denne indsats kun nødvendig første gang, der afholdes et e-læringskursus med brug af Salmons model, og planlægningsprocessen bliver mere effektiv i efterfølgende kurser.

Det forekom os ikke helt så enkelt i begyndelsen at udvikle e-tivities. Vi studerede Gilly Salmons bøger intensivt for at hente inspiration, men vi var dog umiddelbart skeptiske over for hendes foreslåede e-tivities, idet vi ikke var sikre på, at de kunne overføres til en dansk kontekst for universitetsstuderende. F.eks. foreslår hun e-tivities som "What musical instruments do you play?" eller "What's your favorite smell - can you describe it online?" (Salmon 2002). Vi valgte således, også på trin 1 og 2, at udvikle f.eks. socialiserende e-tivities med et fagligt udgangspunkt - der skal dog ikke herske tvivl om, at det kræver kreative e-tivityforfattere at skabe et fagligt relevant, trygt og tillidsvækkende læringsmiljø som inspirerer til dialog.

Følgende e-tivities er eksempler fra hvert af trinene 1, 2, 4 og 5 (for trin 3 eksempel, se Figur 2): 


\section{Trin 1 eksempel: E-tivity 0.2 - Been to the jungle?}

Purpose: to practice writing a message

Task: Have you been inside a forest in a developing country? If yes, respond to the query posted by Carsten, just a few lines, in your group about where and why. If no, respond with a few lines about where you would like to go and why.

Deadline: Must be completed by Thursday 1 September at 22.00 CET.

Trin 2 eksempel: E-tivity 1.3 - Finalise and post your personal presentation in KVL elearning

Purpose: learn to post a personal presentation and share background information with other participants

Task: You have received a draft personal presentation from one of your group members. Use this as inspiration for writing your own personal presentation. When you have completed this brief description, you post it for the other students to read. To post it, go to the "Participants" page (5.2) and click on your own name. Click the "edit" button to edit you profile. The profile you save here will be special to this course. If you wish to make a general profile covering all courses using the KVL elearning system, go to "Users" item (visible when you log on to KVL elearning) and edit your profile there. This distinction allows you to emphasise different aspects of yourself depending on what course you are enrolled in.

Visit the "Participants" page over the next couple of days to the read the descriptions of your co-students. Of course, you can always up-date your profile. For instance, to say that you have completed the course "Applied socio-economics in tropical forestry" :-

Deadline: Thursday 8 September 22.00 CET. 


\section{Trin 4 eksempel: E-tivity 4.1 - What is a forest?}

Purpose: Understanding what is a "forest" is key to planning a number of activities. For instance (i) if you wish to estimate the forest-derived income in a local community, what do you include? Only income related to closed canopy forest? What about from agroforestry? Or (ii) if you wish to convince the World Bank that forest-derived income should be integrated in Poverty Reduction Strategy Papers, then what should be counted as forest income? In this e-tivity, we will discuss this key issue across all participants.

Task: Carefully study the forest definition used by FAO in the Forest Resources Assessment 2000 (FRA 2000). Is this a good and useful definition? Why/ why not? What are the advantages and disadvantages of the definition? How can the definition be improved?

Each participant must post at least one message and respond to at least one message by another participant. At the end of the discussion, one member from each of the small groups will together summarise the entire discussion and post a summary.

Deadline: Friday 30 September at 12.00 CET.

\section{Trin 5 eksempel: E-tivity 9.1 - Uncover present status for international forest negotiations}

Purpose: As you have found in the compendium texts, including the short paper Olsen (2004) found in the left hand menu of the Read section of this module, the international forest negotiations have been difficult and protracted. The paper Olsen (2004) does not include the outcome of the UNFF-5 meeting held in May 2005. The purpose of this e-tivity is to update the paper to include the main outcomes from the UNFF- 5 meeting.

Task: Use the web to find high quality summaries of the forest negotiations at UNFF-5. Synthesise your findings into a brief message and post it. Comment on other postings in your group as appropriate. Each group will prepare a summary of their findings and post in the Discussions for all group. A summary may be no more than 150 words.

Deadline: Friday 28 October at 22.00 CET. 
Desuden udvikledes en række test, som blev tilføjet kurset. Ideen med disse test var, at de studerende kunne tjekke deres forståelse af begreber, etc. For at sikre sammenhæng mellem de studerendes arbejdsform og kursets bedømmelsesform blev det besluttet, at de studerende skulle udføre et bestemt antal test og e-tivities for at få adgang til at deltage i eksamen. Gilly Salmon opfordrer altid sine studerende til at genbruge de indlæg fra diskussionerne, som de har produceret undervejs, i deres eksamensopgaver. Hun forklarer det med, at det virker stærkt motiverende for de studerende, når de ikke opfatter deres udførelse af e-tivities som "spildt arbejde". Vi valgte imidlertid at udvide Gilly Salmons model på dette område af den overbevisning, at der skal være et stærkt incitament i fjernundervisning til at blive ved med at være en aktiv og deltagende studerende. Vi ønskede også at undgå en situation, hvor evalueringsformen var løsrevet fra arbejdsformen. Salmon peger på, at der er to motiver til at få grupper af personer til at arbejde sammen. Det ene er selv-interesse, og det andet er fælles interesse. Selv-interesse kan fremmes gennem ydre faktorer, som f.eks. belønninger, men fælles-interesse kræver tillid og gensidig respekt (Csikzentmihalyi 2003 i Salmon 2004). Vi forsøgte os derfor med at indbygge belønninger, der i endnu højere grad tilgodeser selvinteresse. Derfor var (i) fuldføring af 75\% af modulerne, herunder e-tivities, en forudsætning for at få adgang til deltagelse i eksamen, og (ii) deltagelse i e-tivities en del af bedømmelsen af den enkelte studerende. Underviseren bedømte således hver studerendes deltagelse i hvert enkelt e-tivity som tilfredsstillende eller utilfredsstillende på baggrund af den faglige værdi af indlæggene i hver e-tivity. Dette gav også incitament til deltagelse i trin 1 og 2, der jo ikke er snævert faglige. Modsat Salmon, der fraråder bedømmelse af de studerende før efter trin 3, lagde vi således vægt på evaluering af samtlige aktiviteter.

\section{Udførelse}

Efter kursusstart er det vigtigt at holde øje med hvilke studerende, der har logget sig på og udført den første e-tivity. Her kan e-læringssystemets oversigt over log on hjælpe underviseren til at få overblik. Vores erfaring er, at det kan være nødvendigt at e-maile uden om systemet til de studerende, som af en eller anden årsag har svært ved at få logget sig på og deltage i den første e-tivity. Her må underviseren være opsøgende (på en støttende og opmuntrende måde) og spørge dem, om de har nogle tekniske problemer, eller om der er andre årsager til, at de endnu ikke har logget sig på. Der tegner sig et klart billede af sammenhængen mellem effektiv start og senere deltagelse i diskussionerne. De studerende, der fik logget på hurtigt og fik gennemført e-tivities til deadline, deltog senere aktivt i de faglige dialoger. Generelt set var de studerende, der var mest aktive og deltog med flest indlæg, også de studerende, som senere opnåede det bedste faglige resultat.

Enkelte studerende på kurset havde lidt sværere ved at komme i gang med at skrive indlæg. For disse studerende kan det være en medvirkende faktor, at kurserne foregik på engelsk, og at de derfor følte det som en udfordring både at lære et e-læringssystem at kende samt at formulere skriftlige faglige indlæg på engelsk. Det er derfor vigtigt at være opmærksom på, at e-moderatoren skal være med til at skabe et trygt læringsmiljø. Det er vores erfaring, at det er hensigtsmæssigt, at e-moderatoren anlægger en mere uformel tone i sine indlæg. E-læring uden fysiske møder fordrer, at e-moderatoren så vidt muligt prøver at skrive på en måde, der tager højde for de manglende ansigtsudtryk og kropssprog, som vi normalt bruger i kommunikationen, når vi er sammen. Salmon foreslår, at man som e-moderator anvender nogle udtryk, der afspejler det fysiske miljø, man befinder sig i. F.eks. kan e-moderatoren skrive til de studerende: "Jeg hopper i stolen af begejstring over jeres indlæg” eller "Jeg smilede, da jeg læste at...” (Salmon 2002). Vi anbefaler, at man generelt som e-moderator er opmuntrende undervejs. Ikke-konstruktiv kritik, der offentliggøres skriftligt, så medstuderende kan læse det igen og igen, kan være ydmygende for de studerende. En god e-moderator er desuden opmærksom på, hvor hurtigt den enkelte studerende bevæger sig gennem trin 1 til 5 - der er ingen ens studerende, og fremdriftshastigheden kan være forskellig. 
Kurserne er kendetegnet ved et højt aktivitetsniveau. Det gennemsnitlige antal faglige indlæg per studerende var omtrent hhv. 30 og 20 på de to kurser. Hertil kommer multiple-choice questionnaires, deltagelse i chats, og indlevering af skriftlige opgaver i forbindelse med eksamen. Antallet af studenter-/underviserindlæg var omtrent 5:1. Heri medregnes de underviserindlæg, der starter e-tivities. Generelt gælder, at studenterindlæg er længere end underviserindlæg, og at antallet af underviserindlæg falder, som kurset skrider frem. Ikke blot var der mange faglige indlæg fra de studerende; indlæggene var også generelt af høj kvalitet (kompendiemateriale brugt som teoretisk referenceramme, god anvendelse af teori på cases, kritisk diskussion af kildemateriale, etc.). Der synes ingen tvivl om, at et stort antal deltagere satte høj pris på underviserens virtuelle tilstedeværelse (velkomsthilsner, kommentarer til indlæg, uddybende spørgsmål, etc.).

\section{Evaluering}

Den gennemsnitlige karakter i de fem foregående år (kun data fra et kursus) var fra 7,50 til 8,47. Ved brug af den beskrevne model blev gennemsnittet 9,17 - dette er kun signifikant forskelligt fra et af de foregående år (2002, p < 0.05) men antyder dog, at de studerende klarer sig godt med denne undervisningsform. Det skal dog understreges, at det gode resultat også kan skyldes andre faktorer, f.eks. en dygtig årgang af studerende.

I forbindelse med de studerendes kursusevaluering lavede vi en e-tivity, som vi kaldte "leave your footprints". Her skulle de studerende beskrive, hvordan de havde oplevet at deltage i det første kursus, og de blev bedt om at sætte fodspor til det næste hold af studerende i form af gode råd og anbefalinger. Først og fremmest er det væsentligt at fremhæve, at de studerende var meget ærlige i deres evalueringer, hvilket må ses som et tegn på, at e-moderatoren har skabt et trygt læringsmiljø med rummelighed. De studerende er overvejende enige om, at kurset har været godt og interessant. Der er desuden bred enighed om, at diskussionerne bliver sjovest og mest givtige, når alle deltager. Jo flere indlæg i diskussionerne, jo mere motiveres de studerende til at logge på og lære (vi nåede ikke en overload grænse). En studerende påpeger, at det er vigtigt at tilkendegive, hvis man af en eller anden grund ikke er i stand til at deltage i diskussionerne, sådan at de øvrige studerende ikke behøver at vente på indlæg fra vedkommende. Fleksibiliteten er værdsat af næsten alle. En studerende skrev

"... I have also understood that e-learning is actually not simply a way of teaching used by lazy teachers who don't feel like teaching (hahaha). I think that it is a way of teaching/learning that has its place in the current institutions because it allows flexibility for the students and teachers, while keeping them at work on a steady rhytm."

Flere af de studerende peger på, at der er en direkte sammenhæng mellem e-moderatorens synlighed og faglige inputs og de studerendes motivation. En studerende formulerede det sådan:

"I think that Carsten did a very good job in commenting and participating to our discussion. Furthermore, I really agree that e-moderator participation is crucial as I have felt over the last few weeks (when we have been having less comments and feedbacks due to exams and...) that my motivation has dropped considerably."

Til sidst vil vi nævne et indlæg fra en studerende, som for os at se påpeger, hvordan Gilly Salmons model rejser nogle spørgsmål omkring vores opfattelse af, hvordan universitetsundervisning bør organiseres. Hun skriver:

"The good thing about having e-tivities and questionanaires during the week is that one is forced to read the texts in time and you don't end up starting on the reading just before the exam - not that I would ever do so, but some students do :-)“ 
I den danske universitetsverden har vi måske ikke været i stand til at erkende, at ikke alle studerende (i perioder?) er udstyret med så stor selvdisciplin, som den danske universitetsundervisning fordrer.

Undervisning baseret på five-stage modellen og e-tivities flytter læreren fra en central rolle som instruktør til en mere perifer rolle som coach. Underviseren er, i den gennemgåede case, stadig ansvarlig for udvikling og vedligeholdelse af relevante undervisningsmaterialer og for at sikre faglig fokus i diskussioner. Men hans hovedopgaver er nu at fremme den studerendes selvstændighed i læreprocessen og fremme hendes evner til faglig refleksion (såvel som refleksion over egen læring). De asynkrone netbaserede diskussionfora er med til at fremme mulighederne for refleksion. Dette skal understøttes af underviseren, f.eks. ved (i) at komme med støtte og opmuntrende kritik, eller (ii) afslutte kommentarer med spørgsmål, der giver den studerende mulighed for videre fordybelse og diskussion. I vores case kan det således siges, at "grænserne mellem den traditionelle og den mere stilladseringsorienterede lærer bliver udflydende" (Jensen 2003:3). Dette viser, at modellen, der i udgangspunktet er studenter-centreret, kan tilpasses af den enkelte underviser i en mere traditionel retning, hvis ønsket.

Mange har påpeget, at udvikling og implementering af elearning er tids- og ressourcekrævende (f.eks. Heiberg 2004). Erfaringerne fra de to kurser i denne case er dog, at tidsforbruget til vedligeholdelse, udvikling og implementering af et kursus er det samme som for et kursus undervist på traditionel vis - hvis antallet af studerende stiger til mere end 30-40, vil der dog påløbe nye omkostninger, idet der så bør være mere end én e-moderator per kursus. Derudover skal der investeres et væsentligt beløb (Olsen et al. 2004) for at konvertere et normalt kursus til fjernundervisning.

\section{Brug af modellen i efter- og videreuddannelse}

I princippet kunne ovenstående erfaringer været høstet på kurser, der blev udbudt som en del af KVLs efter- og videreuddannelser. Vi ser således gode muligheder for at bringe modellen i anvendelse i forbindelse med den fremtidige udvikling af KVLs efter- og videreuddannelser. E-tivities synes at være et godt instrument til at fastholde folk, der i øvrigt har en travl dagligdag. Det giver dog ikke mening at bruge modellen direkte på kurser af kort varighed der skal være tid til, at den enkelte deltager kan bevæge sig gennem stadierne. Minimum kursusvarighed er ukendt - vi prøvede med succes i ni ugers forløb, mens Salmon (2004) gætter på 10 ugers varighed som minimum. Det er endvidere vores vurdering, at modellen også med succes kan bringes til anvendelse i blended undervisningsforløb; i den forbindelse er det vigtigt at holde fast i tilstrækkelig tid til trin 2, online socialisering, der nok ikke blot kan erstattes af et kort face-to-face forløb, f.eks. over en weekend.

Vi brugte softwaren ABC Academy, men modellen kan i princippet bruges på alle typer learning management software, blot der er mulighed for elektroniske konferencefora. Der er dog naturligvis visse faciliteter, der virker fremmende på den enkelte deltagers aktivitetsniveau, f.eks. en god og overskuelig sidestruktur. Der er desuden nye tekniske tiltag, der er ønskelige; herunder især udvikling af e-portfolios, hvor den enkelte studerende kan følge sin egen fremdrift, f.eks. ved at give overblik over hvilke e-tivities, der er tilfredsstillende gennemført, og hvilke kompetencer der hermed er opnået.

Slutteligt bør nævnes, at der stadig er rige muligheder for at udbygge evalueringskriterier, herunder standardkriterier for bedømmelse af (i) kvaliteten af den enkelte deltagers indlæg i etivities, (ii) hvorvidt deltagerne evner at opbygge fælles viden, og (iii) den enkelte deltagers evne til at reflektere over egne og andres synspunkter. 


\section{Litteratur}

Bates, A.W. \& Gary Poole, 2003. Effective teaching with technology in higher education. San Francisco: JosseyBass, 2003.

Beard, Colin \& John P. Wilson. 2005. Ingredients for effective learning: the Learning Combination Lock. Enhancing teaching in higher education. Eds. Peter Hartley et al. Oxford: Routledge, pp 3-16.

Csikzentmihalyi, Mihaly, 2003. Good business: leadership, flow and making of meaning. Chatham: Hodder and Stoughton.

Heiberg, Birgitte, 2004. E-learning og kompetenceudvikling. Tidsskrift for universiteternes efter- og videreuddannelse 4 . Online:<http://www.unev.dk/files/birgitte_heiberg_4.pdf $>$ (downloaded 27.3.2006).

Jensen, Helle Bækkelund, 2003. Forandring af undervisningspraksis - hvordan bruger lærere IT i nærundervisningen? Tidsskrift for universiteternes efter- og videreuddannelse 1 (2003). Online:< http://www.unev.dk/files/helle_baekkelund.pdf> (downloaded 27.3.2006).

Monty, Anita, 2005. Velkommen til KVL eLearning - vejledning til studerende. København: KVL, 2005. Online: $<$ http://elearning.kvl.dk/Help/Dansk/guide_dansk_student.pdf $>$ (downloaded 27.3.2006).

Olsen, Carsten S. et al., 2004. Experiences with web-based teaching in forestry. Working Papers No. 1-2004, Copenhagen, Danish Centre for Forest, Landscape and Planning, Copenhagen. Online: $<$ http://www.sl.kvl.dk/Publikationer/Udgivelser.aspx $>$ (downloaded 27.3.2006).

Salmon, Gilly, 2002. E-tivities - the key to active online learning. London: RoutledgeFalmer, 2002.

Salmon, Gilly, 2004. E-moderating - the key to teaching and learning online. London: RoutledgeFalmer, $2^{\text {nd }}$ Edition.

Slevin, James, 2006. E-tivities and the connecting of e-learning experiences through deliberative feedback. Tidsskrift for universiteternes efter- og videreuddannelse 9. 